\title{
ANALYSIS OF GUT FLORA FROM DAMP WOOD TERMITES (TRINERVITERMES SPP.) AND EXTRACTION, CHARACTERIZATION OF CELLULASE FROM THE ISOLATE
}

\author{
NARENDRAKUMAR G ${ }^{1 *}$, SAIKRISHNA NMD ${ }^{1}$, PRAKASH P $^{1}$, PREETHI TV ${ }^{2}$ \\ ${ }^{1}$ Department of Biotechnology, School of Bio and Chemical Engineering, Sathyabama University, Chennai - 600 119, Tamil Nadu, India. \\ ${ }^{2}$ Department of Microbiology, School of Life Science, Vels University, Chennai - 600 117, Tamil Nadu, India. Email: gnaren22@gmail.com
}

Received: 07 February 2017, Revised and Accepted: 21 March 2017

\section{ABSTRACT}

Objective: The objective of the study was to isolate, characterize, identify, and compare the potentials of cellulolytic strains isolated from the gut of damp wood termites (Trinervitermes species) collected from Chennai, Tamil Nadu, India.

Methods: Termites were collected and used as hoard of cellulase producers and screened for the cellulase producers using carboxymethyl cellulose as the sole source of carbon and were authenticated using Congo red plate screening method. The isolates showing a significant zone of clearance were further confirmed by biochemically characterized.

Results: Nine effective isolates were characterized and three strained were used for analysis. The organisms were subjected with substrate, temperature $\left(25^{\circ} \mathrm{C}, 37^{\circ} \mathrm{C}\right.$, and $\left.45^{\circ} \mathrm{C}\right)$, and $\mathrm{pH}$ to optimize the cultural condition. The enzyme activity was estimated using endoglucanase, FPase after incubating at appropriate conditions. Five isolates showing a significant zone of clearance were selected, out of which three belonged to Bacillus and one each to Staphylococcus. Optimization of media and genetic modification of the strains can further convalesce their competence. All the isolates have ensuring application in view of use in future.

Conclusion: An effective strain of bacteria was isolated from the gut of termites can be used as a potential candidate for the production of cellulase in industries.

Keywords: Trinervitermes, Cellulase, Lignocellulose material.

(c) 2017 The Authors. Published by Innovare Academic Sciences Pvt Ltd. This is an open access article under the CC BY license (http://creativecommons. org/licenses/by/4. 0/) DOI: http://dx.doi.org/10.22159/ajpcr.2017.v10i6.17565

\section{INTRODUCTION}

Termites are the most copious terrestrial insects in many damp and dry areas of tropical and subtropical ecosystems [1-3]. They are called as "white ants;" however, they differ from ants in morphological and phylogenetical characters [4]. Termites are polymorphic insects, living in large groups of some hundred to several million individuals, comprised reproductive (Winged) forms together with numerous sterile soldiers and workers $[5,6]$. All termites live in colonies within the confines of excavations within wood above-ground, or in subterranean and epigeal nest systems [7]. Termites portray an immense role in terrestrial ecosystem by recycling biomass containing the mixture of cellulose, lignin, and hemicellulose [8-10]. Termites are soil insects that efficiently decays lignocellulose with the aid of the gut-associated microbes to simplify carbohydrate that later fermented to ethanol using fungi.

They are a key functional group of animals in the tropics and can achieve high dense population. Their numerous colonies have great influence in ecosystems.

\section{METHODS}

\section{Collection of termites}

Damp wood termites were collected and identified as Trinervitermes spp. based on their shape and parts. The termites were surface washed with distilled water further dried on a filter paper. The surface sterilization was performed with $70 \%$ ethanol. The head was trimmed off, and the entire gut was removed with sterile forceps and mixed in a mortar and pestle [11].
Isolation of microbes from termite gut

The guts were homogenized in $1 \mathrm{ml}$ of sterile distilled water, centrifuged at 10,000 rpm for 5 minutes to remove large gut debris. The supernatant was serially diluted and spread plate method was performed on nutrient agar, agar and plate count agar. Colonies were picked up from the agar plates after incubating at $37^{\circ} \mathrm{C}$ overnight and inoculated into respective broths [12].

\section{Isolation and generic level identification}

From the resultant Petri plate of enumeration study of crushed mixture of termite, nine types of bacterial colonies were obtained. These colonies were isolated and cultured in individual Petri plates [13].

For proper characterization, the colonies were labeled as $\mathrm{NSP}_{1}$, $\mathrm{NSP}_{2}, \ldots . . \mathrm{NSP}_{9}$. Standard procedures of bacterial identification such as gram staining, spore staining, capsule staining, motility, IMViC, and other essential tests were carried out to identify bacteria at least up to the generic level [14].

\section{Screening of bacteria for cellulase production}

Enzyme production

The isolated organisms were inoculated in $150 \mathrm{ml}$ Erlenmeyer flask which contains $30 \mathrm{~g}$ of cellulose initially the moisture content of the substrate is determined. The minimal salt medium was prepared with the following content $(\mathrm{g} / \mathrm{L})$, and the $\mathrm{pH}$ of the mineral salt medium (MSM) is adjusted before sterilization [15].

Ammonium sulfate $-10 \mathrm{~g}$, potassium phosphate $-3 \mathrm{~g}$, magnesium sulfate $-0.5 \mathrm{~g}$, calcium chloride $-0.5 \mathrm{~g}$, yeast extract $-7 \mathrm{~g}$, glucose (dextrose) - $15 \mathrm{~g}$. The MSM was prepared and sterilized [16]. 


\section{Congo red method}

The different bacterial species were inoculated in the minimal medium and were kept in the shaker for 5-7 days. The medium was then filtered and centrifuged at 10,000 rpm for 15 minutes. The agar was prepared with the following composition and autoclaved at $121^{\circ} \mathrm{C}$ for 30 minutes. The medium was poured in the sterile Petri plates and left for 15 minutes. $20 \mu \mathrm{l}$ of the supernatant of centrifuged bacterial medium was added to the wells made in plates using micro pipette. These were incubated at $25-30^{\circ} \mathrm{C}$ for $72 \mathrm{hrs}$. The Petri plates were logged with $1 \%$ of Congo red and left for 15 minutes. The detaining of the plates was done with $1 \mathrm{M} \mathrm{NaCl}$ solution for 15 minutes. The zone of clearance was observed for the cellulose hydrolysis surrounding the colonies [17].

\section{Assay of cellulase}

Endoglucanase assay was performed by incubating $1 \mathrm{ml}$ of crude enzyme with $1 \mathrm{ml}$ of $1 \%$ carboxy methyl cellulose (CMC) in $50 \mathrm{mM}$ sodium citrate buffer $(\mathrm{pH} 4.8)$ at $50^{\circ} \mathrm{C}$ for 30 minutes. At different growth period, the matrix was washed with phosphate-buffered saline, and the cell-free extract was used for analysis. The bacterial crude extract was prepared by centrifuging $10 \mathrm{~mL}$ of cell-free extract at $5000 \mathrm{rpm}$ for 15 minutes. The activity of cellulase was studied, using dinitrosalicylic (DNS) assay method. The assay was carried out as follows. Culture filtrate $0.2 \mathrm{~mL}$ was mixed with $1 \%$ CMC in a test tube and incubated at $40^{\circ} \mathrm{C}$ for 30 minutes. The reaction was terminated by adding $3 \mathrm{~mL}$ of DNS reagent. The tube was then incubated at $100^{\circ} \mathrm{C}$ for 15 minutes followed by the addition of $1 \mathrm{~mL}$ of salt solution. The optical density was taken at $575 \mathrm{~nm}$ against blank. One unit of cellulase activity is defined as the amount of enzyme required to liberate $1 \mu \mathrm{mol}$ of reducing sugars per minute under the assay conditions [18]

FPase assay was performed using $30 \mathrm{mg}$ strip of Whatman filter paper No. 1 under the same conditions with incubation time of $1 \mathrm{hr}$ [19].

The amount of protein in culture supernatant was determined using the method reported by Lowry et al. [20].

\section{Optimization of nutritional parameters for cellulase production}

Bacillus strain that had the ability to utilize various additional carbon sources. It was observed that CMC gave maximum cellulase activity at $1.8 \%$ concentration for enzyme production when compared to other carbon sources [21].

\section{Effect of pH on enzyme production}

Optimization was carried out using minimal medium of 2, 4, 6, 8 and 10. The $\mathrm{pH}$ was adjusted by using $1 \mathrm{~N} \mathrm{HCL}$ or $1 \mathrm{~N} \mathrm{NaOH}$. Then, minimal salt medium was enriched with CMC powder. Autoclaved and then different bacterial $\left(\mathrm{NSP}_{1}, \mathrm{NSP}_{4}, \mathrm{NSP}_{2}\right.$, and $\left.\mathrm{NSP}_{5}\right)$ batch cultures were maintained [22].

\section{Effect of temperature on enzyme production}

Optimization was carried out by placing the substrates containing minimal salt medium and the bacterial ( $\mathrm{NSP}_{1}, \mathrm{NSP}_{4}, \mathrm{NSP}_{2}$, and $\mathrm{NSP}_{5}$ ) at different temperatures of $25^{\circ} \mathrm{C}, 30^{\circ} \mathrm{C}, 35^{\circ} \mathrm{C}, 40^{\circ} \mathrm{C}, 45^{\circ} \mathrm{C}, 50^{\circ} \mathrm{C}$ and $55^{\circ} \mathrm{C}[23]$.

\section{RESULTS}

Identification study:

The organisms isolated were tabulated in Table 1.

\section{Screening of cellulase from isolated organism}

Congo red method was used to identify the potential strain from collection of bacterial isolates identified from the gut of termites (Fig. 1).

\section{Enzyme activity}

The enzyme activity was estimated using CMC as a substrate by DNS method. Table -2 lists the FPase and Endoglucanase activity of different microorganism isolated.

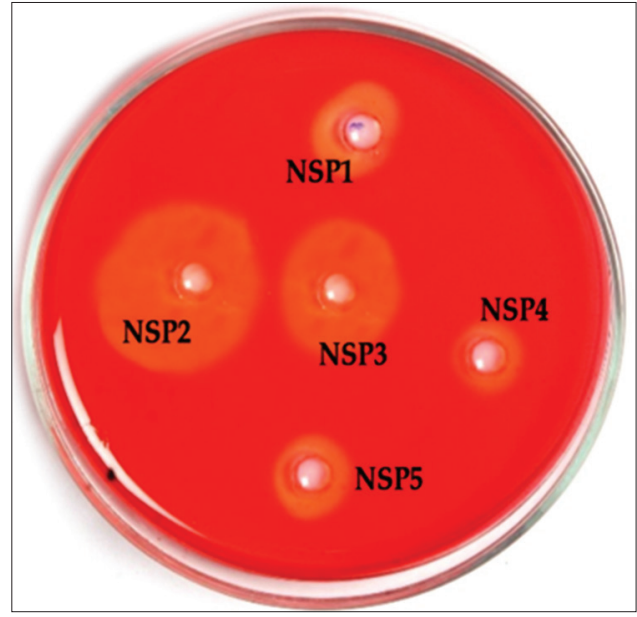

Fig. 1: Screening of cellulase producing organism

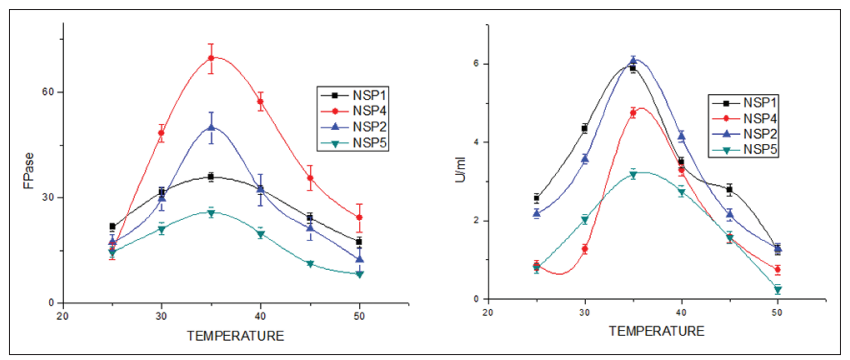

Fig. 2: Effect of temperature on enzyme production

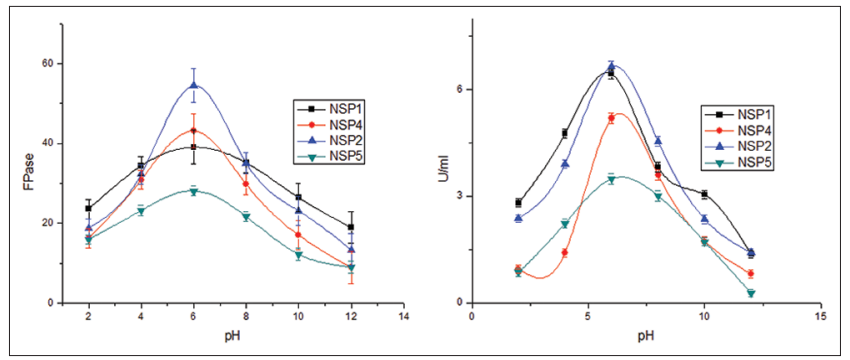

Fig. 3: Effect of pH on enzyme production

\section{Statistical tests}

The results were statistically analyzed using IBM, Statistical Package for the Social Sciences software and analysis of variance with $\mathrm{p}<0.05$.

Effect of temperature on cellulase activity (filter paper and endoglucanase assay)

Cellulolytic enzyme production is also temperature dependent. In the experiments, three different strains of Bacillus and one strain of Staphylococcus subjected at different temperature to study the production of enzyme at different temperature. Temperature is also an essential role in the influences the cellulase production from the organisms. The effect of temperature on cellulase production using high yield strain $\left(\mathrm{NSP}_{1}, \mathrm{NSP}_{4}, \mathrm{NSP}_{2}\right.$, and $\left.\mathrm{NSP}_{5}\right)$ was studied by varying the temperature range from 25 to $55^{\circ} \mathrm{C}(\mathrm{Fig} 2)$.

The maximum production of cellulase was obtained at $35^{\circ} \mathrm{C}$ for $\mathrm{CMC}$ enriched medium that was optimized. The rate of enzyme catalyzed reactions increased with temperature up to a certain limit. Enzyme activity decreases with increase in temperature because of enzyme stability. There are previous reports $[24,25]$ correlating with the results. 
Table 1: Characterization of the different bacterial sample

\begin{tabular}{|c|c|c|c|c|c|c|c|c|c|c|c|c|c|c|}
\hline \multirow[t]{2}{*}{ Sample } & \multicolumn{3}{|c|}{ Staining } & \multirow[t]{2}{*}{ Shape } & \multirow[t]{2}{*}{ Motility } & \multicolumn{8}{|c|}{ Biochemical test } & \multirow[t]{2}{*}{ Organisms identified } \\
\hline & Gram & Spore & Capsule & & & I & MR & VP & $\mathbf{C i}$ & Co & $\mathbf{U}$ & $\mathbf{N}$ & $\mathrm{H}_{2} \mathrm{~S}$ & \\
\hline $\mathrm{NSP}_{1}$ & + & + & - & Bacilli & - & - & - & + & + & - & - & + & - & Bacillus sp. \\
\hline $\mathrm{NSP}_{3}^{2}$ & - & - & - & Bacilli & + & + & + & - & - & - & - & + & - & Escherichia coli \\
\hline $\mathrm{NSP}_{4}^{3}$ & + & + & - & Cocci & - & - & - & - & + & + & - & - & - & Staphylococcus aureus \\
\hline $\mathrm{NSP}_{5}$ & + & + & - & Bacilli & - & - & - & + & + & - & - & + & - & Bacillus sp. \\
\hline $\mathrm{NSP}_{6}^{5}$ & - & + & - & Bacilli & + & - & - & + & + & - & - & + & - & Serratia sp. \\
\hline $\mathrm{NSP}_{7}^{6}$ & + & - & - & Bacilli & - & - & - & + & + & - & - & + & - & Bacillus sp. \\
\hline $\mathrm{NSP}_{8}$ & - & - & - & Bacilli & + & - & + & - & + & - & - & - & + & Salmonella typhi \\
\hline $\mathrm{NSP}_{9}^{8}$ & - & - & - & Bacilli & + & + & - & + & - & - & + & - & + & Proteus vulgaris \\
\hline
\end{tabular}

I: Indole, MR: Methyl red, VP: Voges prokauer, Ci: Citrate, Co: Coagulase, U: Urease, N: Nitrate, $\mathrm{H}_{2} \mathrm{~S}$ : Hydrogen sulfate

Table 2: FPase and endoglucanase assay results for the isolated strains of bacteria

\begin{tabular}{llll}
\hline \multirow{2}{*}{ Sample } & \multirow{2}{*}{ Organisms identified } & \multicolumn{2}{l}{ Cellulase activity } \\
\cline { 3 - 4 } & & FPase & U/ml \\
\hline $\mathrm{NSP}_{1}$ & Bacillus sp. & $36.72 \pm 0.78^{*}$ & $4.02 \pm 0.24^{*}$ \\
$\mathrm{NSP}_{2}$ & Bacillus sp. & $49.45 \pm 0.91$ & $5.65 \pm 0.21$ \\
$\mathrm{NSP}_{3}$ & Escherichia coli & $17.97 \pm 1.21$ & $2.16 \pm 0.18$ \\
$\mathrm{NSP}_{4}$ & Staphylococcus aureus & $38.61 \pm 1.04$ & $4.45 \pm 0.23$ \\
$\mathrm{NSP}_{5}$ & Bacillus sp. & $27.19 \pm 1.54$ & $3.17 \pm 0.17$ \\
$\mathrm{NSP}_{6}$ & Serratia sp. & $11.78 \pm 1.25$ & $1.31 \pm 0.14$ \\
$\mathrm{NSP}_{7}$ & Bacillus sp. & $8.53 \pm 0.92$ & $1.02 \pm 0.11$ \\
$\mathrm{NSP}_{8}$ & Salmonella typhi & $11.29 \pm 0.85$ & $1.26 \pm 0.94$ \\
$\mathrm{NSP}_{9}$ & Proteus vulgaris & $9.25 \pm 0.24$ & $1.11 \pm 0.87$ \\
\hline
\end{tabular}

*Mean square error

Effect of $\mathrm{pH}$ on cellulase activity (filter paper and endoglucanase assay)

The optimal $\mathrm{pH}$ for endoglucanase activity is found to be at $\mathrm{pH} 6$ for bacterial cellulase. Increasing or decreasing the $\mathrm{pH}$ beyond this resulted in decline in enzyme activity. Cellulase yield by $\mathrm{NSP}_{4}$ appeared to depend on $\mathrm{pH}$ value. Results illustrated by Fig. 3 clearly show that the optimum $\mathrm{pH}$ for maximum production of cellulase. It was observed that the activity decreased with more increase in $\mathrm{pH}$ which indicates reduction in the activity $[26,27]$.

\section{CONCLUSION}

The strong relationship between the microbes and the termites was well established. The organisms present in the midgut of termites are responsible for the degradation of lignocellulose material (Wood). By exploiting this phenomenon, the organisms were isolated from the termites and isolated, identified was used for the production of cellulase enzyme. From these isolated, the potential producers were identified and characterized at different temperature and $\mathrm{pH}$. These organisms could be considered as effective candidates for the production of cellulase in large scale.

\section{REFERENCES}

1. Wood TG, Johnson RA. The biology, physiology, and ecology of termites. In: Vinson SB, editors. Economic Impact and Control of Social Insects. New York: Praegar; 1986. p. 1-68.

2. Brauman A, Bignell DE, Tayasu I. Soil-feeding termites: Biology, microbial associations and digestive mechanisms In: Abe T, Bignell DE, Higashi M, editors. Termites: Evolution, Sociality, Symbiosis, Ecology. Dordrecht: Kluwer Academic Publishers; 2000. p. 233-59.

3. Brune A. Termite guts: The world's smallest bioreactors. Trends Biotechnol 1998;16:16-21.

4. Bignell DE, Oskarsson H, Anderson JM. Distribution and abundance of bacteria in the gut of a soil-feeding termite Procubitermes aburiensis (Termitidae, Termitinae). J Gen Microbiol 1980;117:393-403.

5. Collins NM, Wood TG. Termites and atmospheric gas production. Science 1984;224(4644):84-6

6. Collins NM. The utilization of nitrogen resources by termites (Isoptera).
In: Lee JA, McNeill S, Rorison IC, editors. Nitrogen as an Ecological Factor. Oxford: Blackwell Scientific Publications; 1983. p. 381-412.

7. Claus D, Berkeley RC. Genus Bacillus Cohn. In: Sneath PH, editor. Bergey's Manual of Systematic Bacteriology. Vol. 2. Baltimore, MD: Williams and Wilkins Co.; 1986. p. 1105-39.

8. Lee KE, Wood TG. Termites and Soils. New York: Academic Press; 1971.

9. Williams ST, Sharpe ME. Bergey's Manual of Systematic Bacteriology. Vol. 4. Baltimore, MD: Williams and Williams; 1989.

10. Cappuccino JG, Sherman N. Microbiology. A Laboratory Manual. $6^{\text {th }}$ ed. San Francisco, California: Pearson Education Inc.; 2002. p. 215-24.

11. Brauman A, Doré J, Eggleton P, Bignell D, Breznak JA, Kane MD. Molecular phylogenetic profiling of prokaryotic communities in guts of termites with different feeding habits. FEMS Microbiol Ecol 2001;35(1):27-36

12. Sambrook J, Fritsch EF, Maniatis T. Molecular Cloning: A Laboratory Manual. $2^{\text {nd }}$ ed. Cold Spring Harbor, New York: Cold Spring Harbor Laboratory Press; 1989.

13. Utharalakshmi N, Kumar AG, Narendrakumar G. Degradation analysis of different agro-substrates by Aspergillus flavus SB04 using FT-IR. Res J Pharm Biol Chem Sci 2016;7(4):105-12.

14. Fall S, Hawelin J, Ndiaye F, Assigbetse K, Aragno M, Chotte JL, Brauman A. Differences between bacterial communities in the gut of a soil feeding termite (Cubitermes niokoloensis) and its mound. Appl Environ Microbiol 2007;73(16):5199-208.

15. Holt JA, Lepage M. Termites and soil properties. In: Abe T, Bignell DE, Higashi M, editors. Termites Evolution, Sociality, Symbioses, Ecology. Vol. 1. Dordrecht, Netherlands: Kluwer Academic; 2000. p. 389-407.

16. Kappler A, Brune, A. Influence of gut alkalinity and oxygen status on mobilization and size-class distribution of humic acids in the hindgut of soil-feeding termites. Appl Soil Ecol 1999;13:219-29.

17. Mezes PS, Lampen JO. Secretion of proteins by Bacillus 151-185. In: Dubnau DA, editors. The Molecular Biology of the Bacillus. Vol. 2. New York: Academic Press; 1985.

18. Boga HI, Ji R, Ludwig RW, Brune A. Sporotalea propionica genera novel species. Hydrogen oxidizing, oxygen reducing, propiogenic firmicutes from the intestinal tract of a soil feeding termite. Arch Microbiol 2007;187(1):15-27.

19. Leadbetter JR, Breznak JA. Physiological ecology of Methanobrevibacter cuticularis species novel and Methanobrevibacter curvatus species novel isolated from the hindgut of the termite Reticulitermes flavipes. Appl Environ Microbiol 1996;62:3620-31.

20. Lowry OH, Rosebrough NJ, Farr AL, Randall RJ. Protein measurement with the Folin phenol reagent. J Biol Chem 1951;193(1):265-75.

21. Rouland C, Brauman A, Labat M, Lepage M. Nutritional factors affecting methane emission from termites. Chemosphere 1993;26:617-22.

22. Schmitt-Wagner D, Friedrich MW, Wagner B, Brune A. Phylogenetic diversity, abundance, and axial distribution of bacteria in the intestinal tract of two soil-feeding termites (Cubitermes species). Appl Environ Microbiol 2003;69:6007-17.

23. Prabu D, Narendrakumar G. Optimization of process parameters using response surface methodology for removal of phenol by nano zero valent iron impregnated cashew nut shell. Int J Pharm Pharm Sci 2015;7(4):156-61.

24. Narendrakumar G, Kumar S, Vimalan S, Prakash P, Nandagopal S, Kumar RB. Optimization of growth promoters on Desmodium gangeticum (L) DC using RSM CCD and its antioxidants activity. Int J Pharm Pharm Sci 2014;6(8):503-7.

25. Tayasu I, Sugimoto A, Wada E, Abe T. Xylophagous termites depending 
on atmospheric nitrogen. Naturwissenschaften 1994;81:229-31.

26. Utharalakshmi N, Kumar AG, Narendrakumar G. Optimization of cellulase producing Aspergillus flavus SB4 by solid state fermentation using rice bran. J Pure Appl Microbiol 2014;8(2):713-9.
27. Utharalakshmi N, Kumar AG, Narendrakumar G. Optimization of cellulase producing Aspergillus flavus SB4 by solid state fermentation using response surface methodology (RSM)-CCD. Res J Pharm Technol 2015;4(8):349-54 